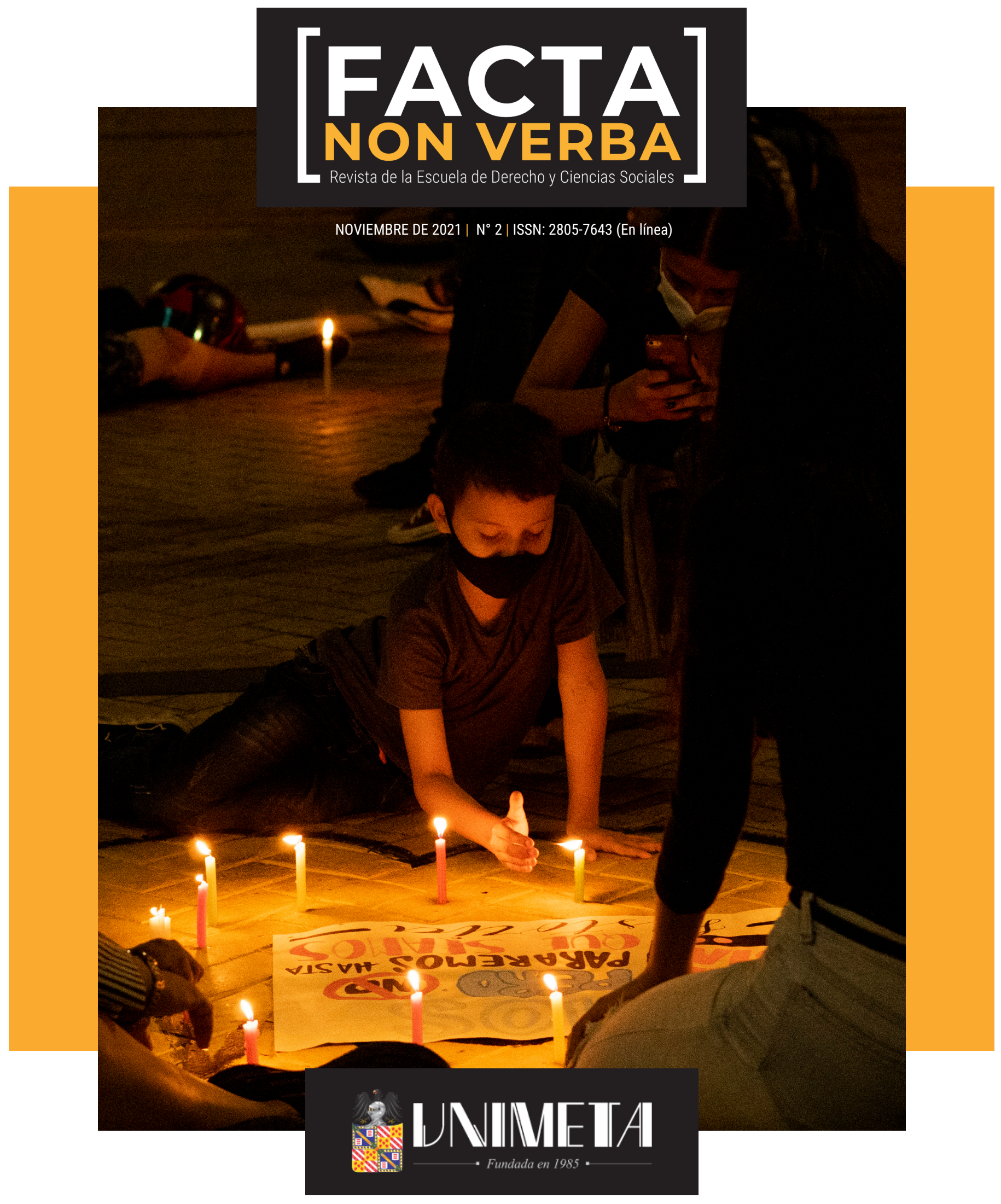




\section{FACTA NON VERBA}

Revista Escuela de Derecho y Ciencias Sociales

ISSN: 2805-7643 (En línea)

Corporación Universitaria del Meta - UNIMETA

\section{Presidenta Sala General Nancy Espinel Riveros}

Rectora

Leonor Mojica Sánchez

Vicerrectora Académica y de Investigaciones Luz Elena Malagón Castro

\section{Decana Escuela de Derecho}

y Ciencias Sociales (e)

Sonia Cristina Preciado Carrero

\section{Editora}

\section{Suhjaila Zuain Sayur}

Jefe Centro de Investigaciones

Socio Jurídicas Jorge Eliécer Gaitán

Editorial

Corporación Universitaria del Meta - UNIMETA

Carrera 32 No. 34B-26, Campus San Fernando

Villavicencio, Meta (Colombia)

Teléfono: (57-8) 6621825 Ext. 130

Fax: 6621827

www.unimeta.edu.co
Cárol Viviana Castaño Trujillo

Edición y corrección de estilo

Juan Manuel Bernate Martínez

Diseño y fotografía

Copyright $\odot$

Corporación Universitaria Del Meta - UNIMETA ISSN: 2805-7643 (En línea)

Noviembre 2021

Villavicencio, Meta, Colombia

Todos los derechos reservados. Ninguna parte de esta publicación puede ser reproducida, almacenada en sistema recuperable o transmitida en ninguna forma por medios electrónico, mecánico, fotocopia, grabación u otros, sin la previa autorización por escrito de la Editorial Corporación Universitaria del Meta-Unimeta y de los autores. Los conceptos expresados en este documento son responsabilidad exclusiva de los autores y no necesariamente corresponden con los de la Corporación Universitaria del Meta-Unimeta y da cumplimiento al Depósito Legal según lo establecido en la Ley 44 de 1993, los Decretos 460 de 1995, el 2150 de 1995, el 358 de 2000 y la Ley 1379 de 2010 . 


\section{TABLA DE CONTENIDO}

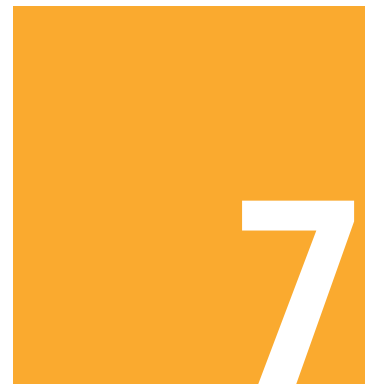

Editorial

Por: Suhjaila Zuain Sayur

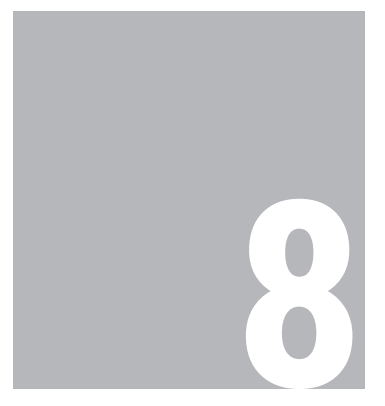

Aquel que sufra de fanatismo, posea poder y actúe con impunidad, podrá transformarse en una bestia Por: Gilberto Rivera Roldán

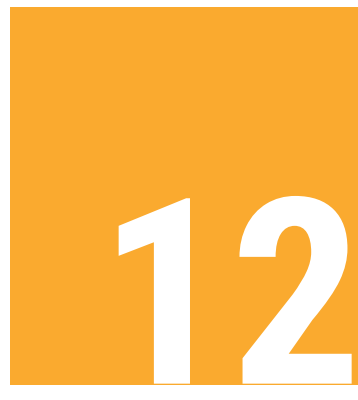

COVID-19y situación carcelaria:

desafíos aplazados

Por: Diana Carolina Villa

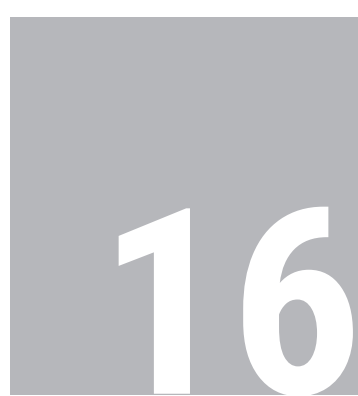

Derecho del consumidor como eficacia de los dere-

chos humanos y la dignidad humana

Por: Sergio Felipe Camargo Guevara

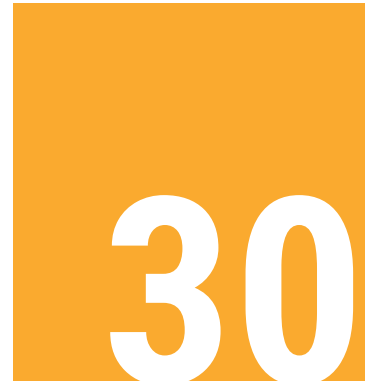

Lecciones de Ruanda para Colombia

Por: Mauricio Beltrán Cristancho

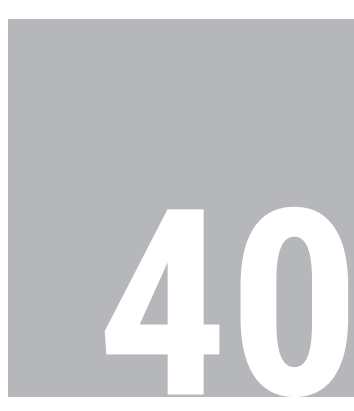

Saqueo histórico

Por: José Mario Castillo Sarmiento

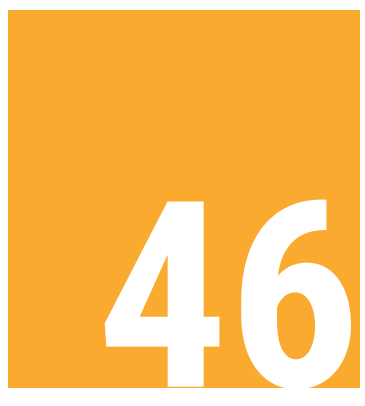

\section{Vencer los temores}

Por: Jhon Gustavo Gallego Gerena

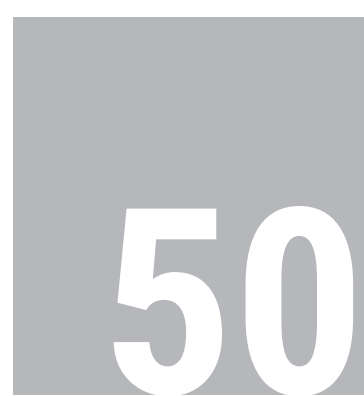

Novedad editorial: libro "Fundamentos de la seguridad social colombiana"

Por: Suhjaila Zuain Sayur 
Editorial

Por: Suhjaila Zuain Sayur

La revista de la Escuela de Derecho y Ciencias Sociales "Facta Non Verba" nació en el año 2013 con el ánimo de ofrecerles a nuestros estudiantes y profesores la oportunidad de estudlant y pas a de plasmar en papel sus vivencias en el mundo académico, este mundo cambiante y a la vez salvaje donde surge el compromiso social.

Esperamos que esta nueva realidad que nos acongoja exhorte a todos nuestros autores para que potencialicen los medios electrónicos y exploren el abanico de oportunidades que ofrece la virtualidad. En este caso, la revista se presenta como un espacio de difusión electrónica para que toda la comunidad sión electrónica para que toda la comunidad acadénica acceda a las contribuciones que estudiantes y profesores hacen al conocimiento en ciencias sociales.

En los textos que componen este nuevo número de Facta Non Verba, se palpa en las letras la pasión por la reflexión crítica, esa misma que permite que tanto autores como lectores aporten e interactúen para construir redes y lazos académicos que fortalezcan la cohesión y colaboración entre las Instituciones de Educación Superior, pues, como verán, la invitación ción Superión entre las instiociones de Educaestá abierta para que compartamos las idea innovadoras, heterodoxas, que desdibujen las cauces habituales del pensamiento dentro y fuera de UNIMETA. 1. Jefe Centro de Investigaciones Socijurúdicas Jorge Elié
cer Gaitán, Corporación Universitaria del Meta - UNIMETA. 
Aquel que sufra de fanatismo, posea poder y actúe con impunidad, podrá transformarse en una bestia

Por: Gilberto Rivera Roldán ${ }^{1}$
Desde los últimos meses me he visto implicesafio que sugiere el supuesto equilibrio entre la vida académica y vida laboral. Llegué afanado a mi oficina y de inmediato comencé a organizar los equipos que utilizaría para mi trabajo, sé bien qué se debe hacer dentro del reportaje gráfico. $\mathrm{Mi}$ compañero y yo salimos apresurados de la oficina, el tiempo nos daba una mala jugada y a este factor se sumaban otros tantos como: atravesar la ciudad en medio de marchas y bloqueos. El reloj avanzaba y aún teníamos trabajo por realizar; nuestro límite de tiempo era as cinco de la tarde y aún quedaban tareas por cumplir: escribir y editar el informe. Estabamos arriesgando demasiado, temíamos que la nota no saliera al aire, y de ser asi, todo el trabajo sería en vano.

estábamos buscando para cubrir el reportaje. Seguimos nuestro camino con las indicaciones del típico ciudadano, en las que resulta igual de fácil perderse que llegar bien.

Nuestros ojos vigilantes descubrieron el lugar pocas cuadras antes de llegar. Al bajarnos del vehículo los vecinos del lugar vieron las cámaras y los equipos, poco a poco se fueron acercando como si vieran en nosotros la oportunidad de narrar lo ocurrido. De inmediato lancé una pregunta al público expectante para ver qué pensaban sobre el ataque perpetrado contra los policias, no se hicieron esperar las respuestas, muchos afirmaban que los del incidente habín sido personas encapuchdas, que habian lle person das, que habian llegado hasta el lugar tirando piedras y lanzando gritos. Las personas que estaban alrededor de nosotros dijeron habe vivido verdaderos momentos de pánico por $\mathrm{e}$ fuego, el caos, y la incertidumbre en medio del descontrol que envolvio al CA. los y entrevistas-los hechos ocuri barrio La Aurora del sur de Bogotá en el momento en el que una turba enardecida se disponía a quemar vivos a 15 policías que se encontraban en el Centro de Atención Inmediata (CAI) de la localidad. Para nosotros esto implicaba un desafío, pues para captar lo ocurrido debíamos tomar decisiones rápidas, tener la suerte de nuestro lado (al encontrarnos con el testigo indicado) $y$, además, lograr recoger un buen material para que el producto final brindara una contundente nota para el televidente.

Llegamos primero CAI de la Candelaria la Nueva, el cual había sido atacado, así lo mostraban los vestigios que quedaban en el lugar. sin embargo para nuestra sorpresa, este no l centro de atención inmediata que nosotros

La narración de los hechos y las respuestas que daban los transeúntes frente a los hechos ocurridos, me hicieron reflexionar en lo que vertirse el ser humano cuando se pue envulto en medio de la fuia colectiva se ve envuelto en medio de la furia colecti esenfreno de la misma.

Al recordar las imágenes de aquellos uniformados que huían en medio de llamas, piedras y palazos, vinieron a mi mente las líneas de Isabel Allende en su obra El amante japonés: "Cualquiera con fanatismo, poder e impunidad puede transformarse en una bestia, como los SS de Auschwitz". Mientras recordaba las escenas de los uniformados y me cuestionaba Correo: gilberto.rivera@academia.unimeta.edu.co 
En los retos que el modelo de Estado Social de Derecho impone frente al aspecto de la dignidad humana y las dificultades históricas (que en materia podrían ser juzgadas), se encuentra, por ejemplo, la configuración de una política criminal Wque impacte de manera efectiva en la disminución de la impunidad y que genere, simultáneamente, las condiciones para el cumplimiento de los fines de la pena (Corte Constitucional República de Colombia. Sentencia C-646/01): prevención general, retribución justa, prevención especial, reinserción social y protección al condenado (Código Penal Colombiano, 2000). A todo esto, se le sumó en el mes de marzo del año 2020 la crisis sanit de

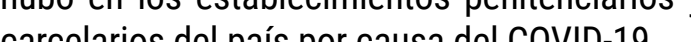

Así las cosas, el gobierno nacional resolvió, mediante la Resolución 1144 de 2020, declarar el "Estado de Emergencia Penitenciaria y Carcelaria" por las causales dispuestas en el artículo 92 de la Ley 1709 de 2014, que modifica el artículo 168 de la Ley 65 de 1993, en todos los Establecimientos de Reclusión del Orden Nacional a cargo del INPEC. Esto se desarrolló con el objetivo de prevenir y controdesarrolocon é lar la propagación del covid-19 y así mitigar los efectos de este en la población que se encuentra privada de su libertad, además de as condiciones en las cuales se encuentran en medio del hacinamiento: la escases de provisiones, el nulo tratamiento de agua potable, la mala alimentación, la falta de baterías sanitarias como duchas y elementos de aseo; todos estos son factores que han sido documentados y reconocidos por la Corte Constitucional como un estado de cosas inconstitucionales, que caracteriza a los establecimientos penitenciarios y carcelarios.

No obstante, el problema de los centros penitenciarios se convertía en una situación que le pasaba factura al Estado colombiano por el incumplimiento de los deberes de respeto y garantía (artículos 1 y 2 de la Convención Americana de Derechos Humanos) con la población que se encuentra privada de su libertad. Durante largos años defensores de Derechos Humanos, internos, familiares y miembros de la comunidad internacional se encontraban a la espera de las soluciones para las necesidades básicas que la situación demandaba.

La situación llegó hasta el punto que la Corte Interamericana de Derechos Humanos el 9 de abril, emitió la Declaración 1/20, titulada "COVID-19 y Derechos Humanos: los problemas y desafios deben ser abordados con perspectiva de Derechos Humanos y respetando las obligaciones internacionales", en la cual reconoce que la sorpresiva pandemia global ocasionada por el coronavirus, representa desafíos extraordinarios para los Estados y para la sociedad merican de Derechos Hum la pide a mos reducir los nives le pobe a los estados reducir los niveles de sobrepoblación y hacinamiento, y disponer -de forma raciona y ordenada- medidas alternativas a la privación de la libertad. Fue entonces cuando el Decreto 546 del 14 de abril de 2020 adoptó:

medidas para sustituir la pena de prisión y la medida de aseguramiento de detención preventiva en establecimientos penitenciarios y carcelarios por la prisión domiciliaria y la 
detención domiciliaria transitorias en el lugar de residencia a personas que se encuentran en situación de mayor vulnerabilidad frente al COVID-19, y se adoptan otras medidas para combatir el hacinamiento carcelario y prevenir y mitigar el riesgo de propagación, en el marco del Estado de Emergencia Económica, Social y Ecológica.

Más adelante, se expidió la Resolución 843 del 26 mayo del año 2020, "por medio de la cual se adopta el protocolo de bioseguridad para el manejo y control del riesgo de coronavirus - COVID-19 en establecimientos penitenciarios

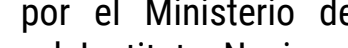
Justicia y del Derecho, el Instiuto Naciona Penitenciario y Carcelario INPEC y la Unidad de Servicios Penitenciarios y Carcelarios USPEC, dieron cuenta de las gestiones adelantadas en vía de abordar aquellas problemáticas.

Sin embargo, la negligencia del Estado en la protección de la salud, la vida y la integridad personal de las personas privadas de su liberad como forma de san discusión. La deteción oportuita, sigue en dis COVID19, el desabastecimiento de alimentos, la falta de agua potable y de medicamentos al interior del establecimiento carcelario, el aislamiento de los internos confirmados como portadores del virus, la aplicación de enfoques diferenciales, entre otros factores, siguen siendo grandes desafios para el Estado colombiano.

\section{Referencias}

Código Penal Colombiano. Ley 599 del 2000. 24 de julio de 2000 (Colombia).

24 de Selombia. Sentencia C-646/01. Expediente D-3238. 21 de junio de 2021.

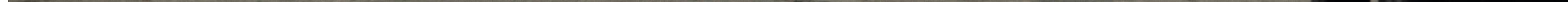


Derecho del consumidor como eficacia de los derechos humanos y la dignidad humana ${ }^{1}$

Por: Sergio Felipe Camargo Guevara ${ }^{2}$

\section{Resumen}

El trabajo tiene como objetivo realizar un análisis histórico y actual del derecho del consumo en Colombia, contrastando las posturas académicas clásicas y la más contemporáneas de algunos doctrinantes. La metodología es deductiva, analítica, hipotético histórica y dialéctica, enfocada a producir resultados que aporten a la discusión que existe entre el derecho del consumo, los derechos humanos y la dignidad humana. Se concluye la importancia que tiene el vínculo existente para satisfacer estos derechos, específicamente en el territolo, y su carácter egal y fundamental para el estado.

Palabras clave: derechos humanos, constitución, derechos fundamentales, consumidor, mercado.

Keywords: human rights, constitution, fundamental rights, consumer, market.

Introducción

El derecho del consumo nace como una forma de proteger a la parte débil, el consumidor, de proteger a la parte débil, el consumidor,
por lo que el legislador se enfocó en una por lo que el legislador se enfoco en una protección de los derechos administrativos y del derecho privado. No obstante, el ligamen entre los derechos del consumidor, derechos constitucionales y derechos humanos ha tomado auge en dirección de los derechos fundamentales, esto a razón de la protección aunada a los derechos económicos, sociales, culturas y ambiectas (DESCA) de tercera culturales y ambintales (DESCA) de tercera generacion, que le ha dado mayor relevancia al tema. Por consiguiente, el presente escrito pretende abordar esa relación de los derechos humanos con el consumo, y demostrará que los derechos de los consumidores pueden ser tomados desde la perspectiva de los derechos humanos, y desde una perspectiva

Abstract:

The work aims to carry out a historical and current analysis of consumer law in Colombia, contrasting the classic and more contemporery academic positions of some doctrimpoThe methodology is deductive, anatical The methodology is deductive, analytical, hypothetical, historical and dialectical, focused on producing results that contribute to the discussion that exists between consumer law, human rights and human dignity. The importance of the existing link to satisfy these rights is concluded, specifically in the territory of Colombia, in this century, and its legal and fundamental nature for the state.

"La ley natural no es otra cosa que la luz de la conciencia, o la ley de nuestro interés dirigido por la razón" (Napoleón, 1821, p. 95).

\section{Derechos Humanos y Empresa}

a) La evolución de los Derechos Humanos.

Después de la Segunda Guerra Mundial, los países se reunieron y decidieron plantear e futuro del mundo con un proposito de paz, así

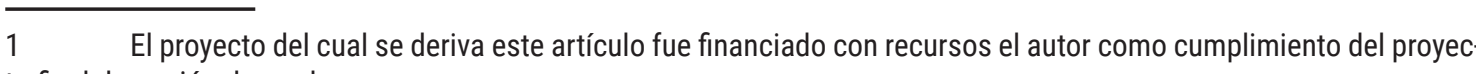
to final de opción de grado.

2 Estudiante de la Facultad de Derecho, Universidad Militar Nueva Granada, Colombia. Integrante del Semillero de Investigación de Protección al Consumidor, Universidad Militar Nueva Granada. Sergio.camargo@unimilitar.edu.co 
crearon la Declaración Universal de los Derechos Humanos (Papacchini, 1998).

Se trata de un acontecimiento sin precedentes en la historia de la humanidad: al final de una guerra sangrienta y después de los horrores del fascismo y del nazismo, se consolida un consenso entre la mayoría de los pueblos de la tierra acerca de unos principios básicos que regulen la convivencia pacífica. (Papacchini, 1998, p. 138)

El papel que juegan las empresas en el cumplimiento de esos derechos es fundamenta cles desde el punto de vista de la proteción a consumidor, pues las mismas son las principales encargadas de velar por la calidad de sus bienes y servicios puestos en circulación en el mercado de los consumidores racionales. Sin embargo, en muchas ocasiones, la línea de la responsabilidad social empresarial, con las estrategias desleales utilizadas por las empresas para aumentar sus ganancias, puede verse comprometida en un juego que busca objetivos opuestos en lo que se refiere a la satisfacción de los derechos humanos de los consumidores racionales. Se evidencia que existe un ligamen entre los derechos del consumidor, los derechos humanos y las empresas, por ejemplo, en el tema de las etiquetas de productos comestibles, pues muchas veces no son claras y ponen en riesgo derechos tan importantes como la vida, al vulnerar el derecho de información, que protege a los consumidores (Guarnizo y Narváez, 2019).

El doctor Juan Carlos Villalba es uno de los el ámbito del derecho de consumo y aborda el rol que juegan las empresas en el cumplimiento de los Derechos Humanos,
El derecho de la protección al consumidor es relativamente nuevo en Colombia y tomo un gran impulso con la expedición y er expedición y entrada en vigencia de la Ley 1480 de 211, conocida como el Estatuto de la Protección al Consumidor. No obstante, la principal norma de protección al consumidor es la constitución política colombiana y en ella existe una serie de postulados que definen la forma y el espíritu de las normas que buscan dicha protección. (Villalba, 2018, p. 45)

Las empresas, a su vez, tienen que ver con las leyes de la economía, así una constitución a la economía socia

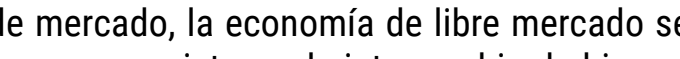
de donde los agentes económicos gozan de unos derechos y unas libertades, pero estas libertades no son absolutas, pues todo derecho tiene su límite para que este pueda estar en armonía con los otros derechos, asunto establecido en la Carta Magna. Dentro de estos límites que define la Constitución Política de Colombia, se encuentran los de la protección a la libre competencia, el ambiente, el patrimonio, interés social, entre otros, que buscan unio función social de la empre, que buscan una función social de la empresa, así, estando esto derechos ligados al derecho del consumo, po ser el derecho de la protección al consumidor un derecho social de mercado, polifacético, poliédrico, se apoya en la idea de un derecho que en algunos ordenamientos jurídicos ya es pensado seriamente como un derecho humano, que busca proteger a la parte débil del contrato, que en este caso es el consumidor, ya que este se enfrenta a contratos de adhesión obligatoriamente. En muchos des te. En muchos de los casos, esta parte débil debe aceptar si quiere pañan en su existencia y participación activa dentro de las relaciones de mercado diarias (Villalba, 2018).

Cuando hablamos de las relaciones comerciales, el consumo, las empresas, la economía, el Estado, el bienestar de las naciones, la libertad del comercio, sus contras como el monopolio, las malas prácticas mercantiles, y el deber ser económico, moral, ético, normativo y político, difícilmente vamos a poder encontrar un autor magno, que pueda decirse que sea una persona diestra en semejante cantidad de temas. Sin embargo, difícilmente no es lo mismo que imposible Para Adam Smith uno de los padres del Liberalismo, esta tarea no fue vista como imposible, pues redactó una obra maestra en 1776, titulada: "Una investigación sobre la naturaleza y las causas de la riqueza de las naciones". Smith fue referencia fundamental de la escuela clásica de economía, que agrupa a figuras como Malthus, Say, Ricardo, John Stuart Mill e incluso influyó en la creación de sistemas alternos, creados por personas que cuestionaron el sistema clásico de su momento, como el mismo Karl Marx (Cole, 1995)

Cuando Smith insiste en explicar el funcionamiento de la economía real, con todo su marco
institucional, básico para el crecimiento económico, describe un "sistema de libertad natural", yico, describe un "sistema de libertad natural", y afirma que se impone por sí mismo, debido a la naturaleza humana, pero necesita un complejo entramado político y legislativo, es decir, la mano visible del Estado y las instituciones. Este orden bien aplicado genera un respaldo a la riqueza, que se refleje en un incremento en el nivel de vida del pueblo, dedicando un espíritu anti monopólico, pues demuestra cómo los diversos grupos económicos consigueno los diversos grupos económicos consiguen privilegios del Estado sobre la base de fingir que representan los más amplios intereses de la sociedad, a partir del desvío forzado de capital hacia una u otra rama específica, lo que da lugar a unos precios mayores y una producción menor (Smith, 1776).

Pero uno de sus aportes más importantes a derecho del consumo es que lo liga a su teoría económica, por lo tanto, lo liga al capitalismo mismo, a las empresas y todo lo que ello representa o vincula. Smith (1776) afirma que:

Una cosa es defender al capitalismo, y otra cosa muy distinta es defender a los capitalistas, que sólo son útiles a la sociedad en la medida en que compitan en el mercado ofrecado ofreciendo bienes y servicios buenos y baratos, con lo que los consumidores se benefician ción. (p. 9)

Con esto se evidencia que, aunque Smith apoyaba la libertad natural, también era un ávido defensor del proteccionismo monopólico, el cual, según él mismo, atentaba contra el interés general, por lo tanto, se puede afirmar que Smith defendia a los consumidores, lo cua

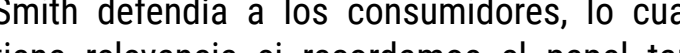
iene relevancia si recordamos el papel tan importante de Smith en la creación de la teoría

\section{b) Los Derechos Económicos, Sociales, Cul-} turales y Ambientales -DESCA

La Convención Americana sobre Derechos Humanos (CADH o Convención Americana) busca materializar la idea que el ideal del se humano libre, exento del temor y de la miseria solo puede realizarse si se crean condiciones crean condiciones que permilan a cada persona gozar de sus deque peritan a cada persona gozar de sus de- 
políticos. Según dicha convención, los estados partes se comprometen a adoptar providencias, tanto a nivel interno como mediante la cias, tanto a cooperacion invecialmente económica y técnica, para lograr progresivamente la plena efectividad de los derechos que se derivan de las normas económicas, sociales y sobre educación, ciencia y cultura, contenidas en la Carta de la Organización de los Estados Americanos (Carta de la OEA). Esta Carta fue complementada por el Protocolo de Buenos Aires. Por su parte, el Protocolo adicional a la Convención Americana sobre Derechos Humanos en Materia de Derechos Económicos, dor), tambiel dor), también reafirma, desde su narrativa, la estrecha relación que existe entre la vigencia de los derechos económicos, sociales y culturales y la de los derechos civiles y políticos (Ibáñez, 2020).

Las relaciones económicas y sociales a partir de la modernidad, la fabricación en serie y la Revolución Industrial permitieron el surgimiento intrínseco de un grupo social, así es como los consumidores y usuarios de bienes y servicios genericon un nexo estructural entre servicios generaron un disciplinas: la ética, la economía, la sociología y el derecho, para la búsqueda de la garantía de sus intereses. La filosofia de este nuevo derecho abarca entonces tres dimensiones humanistas: de promoción, del bienestar general y la calidad de vida, y de contención frente al poder y al sistema económico. El surgimiento del novedoso derecho del consumo es una respuesta a la necesidad de proteger la natural vulnerabilidad de una de las partes intervinientes en el mercado, que bien podría colocar en riesgo a mercado, que bis podía colocar en riesgo a la misma economia de mercado; la tendencia que las leyes de defensa de la competencia no están para proteger al mercado, sino al destinatario último de la actividad económica, es deci el consumidor (Herrera, 2013)

Algunos autores se atreven a encasillarlo en una categoría de derecho fundamental, po ejemplo, Herrera (2013) afirma: "El derecho de consumo es parcialmente un derecho humano fundamental, de tal forma que cada Estado debe respetar y hacer respetar a los sectores económicos este esencial principio de acceso a un consumo digno" (p. 34).

Por lo cual, podemos empezar a ver la importancia que tiene el derecho del consumo ya desde la doctrina.

La Constitución Política de Colombia incluye un régimen económico en su Título XII. Allí, se encuentra consagrado el deber del Estado colombiano de evitar cualquier abuso de posición dominante en el mercado nacional (art. 333) así como el de intervenir en la economía con el fin de conseguir "el mejoramiento de la calidad de vida de los habitantes, la distribución equitativa de las oportunidades y los beneficios de tesarro y a presción de un anbie (3) sano (art. 334). El hiberalismo económico es susceptible de ser malinterpretado mediante sofismas, relacionando pasividad estatal con libertad de comercio; sin embargo, acontecimientos globales recientes como la crisis de 2008, demuestran que las cosas funcionan mal cuando el Estado es pasivo, y surgen oligopolios y monopolios, el abuso de posición dominante, las negociaciones prohibidas en contratación con las administraciones públicas, las centrales de compras que dejan fuera a, al pequeño y mediano comercio, los generalizaminijobs, salarios basura, y bonos basura. La
Corte Constitucional ha emitido jurisprudencia relacionada con los DESC (derechos económicos sociales $y$ cos socia Constitución Política, tratando de generar un ambiente de intervención Estatal, sin embargo, existen intereses económicos en la clase dirigente que han terminado por sacrificar el interés general, perjudicando a los consumidores y las empresas pequeñas, condenando al país a un estancamiento económico (Acosta, 2017).

Es importante entonces, entender el vínculo que se forma entre el derecho del consumo y los DESCA, para así asimilar las diferentes posturas doctrin as se forman por esta posturas doctrinales que se forman por esta asociación. Se puede hacer una analogía con las diferentes facciones jurisprudenciales del pasado relativas a la "tesis de la Conexidad". La Corte Constitucional de Colombia en la Sentencia T-760 del 2008, en un debate profundo, consideró que:

La acción de tutela era una herramienta orientada a garantizar el goce efectivo de los derechos de libertad clásicos y otros como la vida No obstante también desde su inicio vida. su inicio, la jurisprudencia entendió que algunas de las obligaciones derivadas del derecho a la salud, por más que tuvieran un carácter prestacional y en principio fuera progresivo su cumplimiento, eran tutelables directamente, en tanto eran obligaciones de las que dependían derechos como la vida 0 la integridad personal.

Esto ha sido denominado la tesis de la conexidad: la obligación que se deriva de un derecho constituciona constitucional, el a tutela si se encuentra en conexidad con el goce efectivo de un dercho fundamental. Además, se reconoció ya por vía jurisprudencial consti- tucional que hay órbitas de la protección de un derecho como puede ser la salud, o cualquier otro derecho expresamente reconocidos por . Constifución como "derechos de aplicación inmediata", tabs como la vida la iguldad, la dignidad humana y que los mismos deben garantizadas por vía te tuta por garantizadas por vía de tutela, por la grave afección que implicarían para la salud de la person y para otros derechos ligados a los mismos (Corte Constitucional de Colombia, Sentencia $\mathrm{T}-760,2008)$. Lo cual es bastante significativo para el derecho del consumo, pues el mismo es reconocido en la Carta Magna de Colombia de 1991, en su capítulo tres, incluido dentro de los derechos colectivos $y$ del ambiente; $y$ las san-

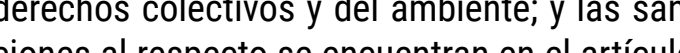
78: " 78. "Serán responsables, de acuerdo con la ley, quienes en la producción y en la comercialización de bienes y servicios, atenten contra la salud, la seguridad y el adecuado aprovisionamiento a consumidores y usuarios".

Por lo anterior, es prudente afirmar que el derecho del consumo también se puede tutelar, por la conexidad que tiene el mismo con otros derechos constitucionales de aplicación inmede los de los más recientemente reconocidos: el de 列 jurisprudencia se contemplaba que:

La funda mentalidad dependía entonces, de su vínculo con otro derecho distinguido como fundamental - tesis de la conexidad -, y por tanto únicamente podía ser protegida por vía de tutela cuando su vulneración implicara la afectación de otros derechos de carácter al, como el derecho a la vida, la dignidad humana o la integridad personal. (Corte Constitucional de Colombia Sentencia T-161, 2013) 
nación e Intolerancia (A-69). La convención, firmada por Colombia en 2014, impone a compromiso de prevenir, eliminar, prohibir y sancionar todos los actos y manifestaciones de discriminación e intolerancia, de conformidad con sus normas constitucionales y con las disposiciones de tal mecanismo internacional (Sentencia T-291,2016). Este precepto normativo señala quince actos constitutivos de discriminación, entre los cuales, se destacan los siguientes:

(i) Cualquier distinción, exclusión, restricción 0 preferencia aplicada a las personas con o preferencia aplicad base en su condición de victima de discriminación múltiple o agravada, cuyo objetivo 0 resultado sea anular o menoscabar el reconocimiento, goce 0 ejercicio de derechos y libertades fundamentales, así como su protección, en igualdad de condiciones.

(ii) Cualquier restricción discriminatoria de goce de los derechos humanos consagrados en los instrumentos internacionales y regionales aplicables y en la jurisprudencia de las cortes internacionales $y$ regionales de derechos humanos, rechos hospecial los aplicables a las minorías o grupos en condiciones vulnerabilidad y sujetos a discriminación. (iii) La restricción del ingreso a lugares públicos o privados con acceso al público por las causales recogidas en el artículo 1.1 de la Convención. (Convención Interamericana contra toda forma de discriminación e intolerancia (A-69), 2013, p.4)

La dignidad humana, por tanto, está muy ligada al derecho del cons su mas clara expresión, este un vínculo innegable para su realizaimplica garantizar las condiciones necesarias para una existencia materialmente apropiada y acorde con el proyecto de vida que cada ciudaun mandato imperativo de las autoric un manda ins autoridades públicas y de los particulares para que adopte las medidas necesarias de protección indispensables para salvaguardar los bienes jurídicos más preciados para el Estado (Sentencia C-147 de 2017). Este proyecto de vida de cada ciudadano, como lo define la corte, se entiende desde la dimensión y la satisfacción de las necesidades de cada ser humano para suplir su existencia, encontrándose allí, el derecho del consumo como vehículo para el cumplimiento colo como lo define la Cey 1480 de 2011 (Estatuto de or), en su artículo número 1 :

Esta ley tiene como objetivo la protección de los consumidores frente a los riesgos para su salud y seguridad, el acceso de los consumidores a una información adecuada, de acuerdo con los términos de esta ley, que les permita hacer elecciones bien fundadas. La educación del consumidor y la libertad de constituir organizaciones de consumidores, midores, con la oportunizad para esas organiziones de hacer ofr sus opiniones en los procesos de adopción de decisiones que las afecten en conjunto, con la protección especial a los niños, niñas y adolescentes, en su calidad de consumidores, de acuerdo con lo establecido en el Código de la Infancia y la Adolescencia de la ley colombiana.

En estos postulados se evidencia que el derecho del consumo es una garantía de la dignida humana, siendo también, una con los derechos fundamentales conexos, ya reconolibertad y la igualdad, protegidas por artículo
13 , y la calidad de bienes y servicios, vigilados por las organizaciones de consumidores, buscando proteger la salud y la vida (artículo 78 de la Constitución Política de Colombia). Estas medidas, sumadas a la libre competencia económica del artículo 333 , que busca proteger de los abusos de la posición dominante en el mercado nacional, tiene un fundamento teleológico pro consumidor, pues estos factores que protege son precisamente los mismos que busca defender el derecho del consumo, e igualmente los que diferentes manifestaciones del derecho comunitario latinoamericano han protegido por a dimension universal del diferentes aspectos del derecho internacional público y privado en general, si se analiza, desde una perspectiva global, trasnacional.

Se concluye entonces, que el derecho del consumo complenes pate de los tineamientos identificados pe de los tres lineadignidad humana, y que son diferenciables:

(i) la dignidad humana entendida como autonomía o como posibilidad de diseñar un plan vital y de determinarse según sus caracteristicas; (ii) la dignidad humana entendida como ciertas condiciones materiales concretas de existencia; y (iii) la dignidad humana entendida como intangibilidad de los bienes no patrimoniales, integridad física e integridad moral 0 , en otras palabras, que los ciudadanos puedan vivir sin ser sometidos a cualquier forma de humillación o tortura. Por tanto, se puntualizan tres expresiones de la dignidad humana rdenamientoju miento jurídico y por tanto del Estado, en este sentido principio constitucional; y (iii) derecho fun- damental autónomo. (Corte Constitucional de Colombia, Sentencia T-291, 2016)

b) Los Derechos del Consumidor como Derechos Humanos

Jurisprudencialmente se ha definido la protección al consumidor como el ordenamiento jurídico que regula las relaciones de consumo originadas en el intercambio de bienes y servicios entre productores, proveedores, expendedores y consumidores; y que tiene un carácter poliédrico:

(i) Un contenido esencial del derecho del consumidor es la pretensión a obtener bienes y servicios que reúnan unos requisitos mínimos de calidad y de aptitud para satisfacer sus necesidades.

(ii) Su objeto incorpora pretensiones, intereses y situaciones de orden sustancial (caldad de bienes y servicios; información).

(iii) Su objeto incorpora pretensiones de orden procesal (exigibilidad judicial de garantías; indemnización de perjuicios por productos defectuosos; acciones de clase etc.). (iv) Su objeto incorpora pretensiones de (iv) Su objeto incorpora pretensiones de orden participativo (frente a la administración pública y a los organos reguladores) (Corte Constitucional de Colombia, Sentencia C-1141, 2000)

Para el cumplimiento de estas protecciones legales, existe la Superintendencia de Industria y Comercio con funciones ordinarias asignadas, según la Constitución en su artículo 115 y la ley para dar vigilancia y control al artículo 78 de la misma Carta Magna:

Serán responsables, de acuerdo con la ley quienes en la producción y en la comerciali- 
zación de bienes y servicios, atenten contra la salud la seguridad y el adecuado aprovisionamiento a consumidores y usuarios.

El Estado garantizará la participación de las organizaciones de consumidores y usuarios en el estudio de las disposiciones que les conciernen. Para gozar de este derecho las organizaciones deben ser representativas y observar procedimientos democráticos internos. (Constitución Política de Colombia, 1991, p. 32)

Sin embargo, dependiendo de la responsabilidad y las actuaciones, se puede ver resuelto por la justicia con minicioso administrativo, según del caso, y puede imponer sanción por resarcimiento a daños causados por defectos de productos o servicios, calidad e idoneidad, independientemente del vínculo contractual entre productor y distribuidor, ya que solo en pocos casos el fabricante pone directamente en la circulación el bien y lo coloca en manos del consumidor final, por tanto, la responsabilidad del productor y del distribuidor surge "ex constitutione" y puede por ello ser deducida por el consumidor del producto (et usuario), con independencia de que exista o no un vínculo contractual directo con los primeros (Corte Constitucional de Colombia, Sentencia C-1141, 2000).

Es por esto que, en el pasado, la Corte Constitucional de Colombia, cuando han surgido disputas entre productores, proveedores, expendedores y consumidores, ha citado los derechos fundamentales, como la salud de consumidor frente al derecho a la ganancia con un roductor, expendedor o proveedor. La autoridad ha afirmado que es la autoridad sanitaria sobre contaminación de productos alimenticios sea de público conocimiento, así tenga repercusiones económicas sobre los productores, proveedores, expendedores, pues el dere dores, pues el derecho a la salud del consumidor ha de presumirse de interés superior a derecho económico alegado por las empresas. En consecuencia, el derecho del consumidor se deriva jurisprudencialmente del derecho fundamental, lo cual es uno de los pronunciamientos más importantes en relación con el consumo (Corte Constitucional de Colombia, Sentencia T 333, 2000)

El tema y sus aristas se han debatido en Colom bia en contexto del Derecho en Latinoameejemplo, en el ámbito constituciona peruano, Julio Durand Carrión hace un análisis muy importante partiendo de la naturaleza jurídica de los derechos del consumidor, y nos relata que, en efecto, el hombre, es decir, el se humano, es sujeto de necesidades desde que nace e incluso desde antes de nacer, aunque en ese momento satisface sus necesidades a través de la madre. Por lo tanto, el hombre, en cuanto sujeto necesitado, acude al mercado para satisfacer sus requerimientos; una vez que seintegra integra a este, establece relaciones con os agentes económicos para poder garantiza dicho fin. En ese tránsito del hombre hacia e mercado, el estado ha establecido una serie de derechos y prerrogativas para el individuo, puesto que por mandato constitucional el fin supremo de la sociedad y del estado es la persona humana. Aquellos derechos a los que específicamente nos referimos son los que hoy llamamos derechos del consumidor: el derecho a la información, a la idoneidad de productos servicios, el derecho a a salud, la seguridad, rescios, el de a la idoneidad de productos y respeto a su intimidad y su dignidad, el derecho derecho a la igualdad de trato en las transaccio- nes comerciales, el derecho a la reparación de los daños, el derecho a ser representado, entre

Por lo tanto, creemos que es válido postular una aproximación teórica a los derechos humanos de los consumido los derechos huporque los consumidores en el mercado, porque es evidente que en las prácticas de este se vulneran los derechos de aquellas, se trata de una realidad innegable. Se requiere, por ende, un enfoque sistémico y principista de derechos humanos para equilibrar las cosas y lograr el pleno ejercicio y respeto de los derechos fundamentales de las personas en el mercado. (Durand Carrión, 2019, p.7)

Se ha visto un enfoque similar desde una entidad del derecho público en el ámbito de Colombia cuando la Superintendencia de Industria y Comercio (SIC) ordenó a Virgin Mobile Colombia S.A.S, a través de la resolución 92696 de 2018, abstenerse de emitir y divulgar campañas publicitarias que vulneren derechos fundamentales, con argumentos basados en la vulneración de la Constitución Política de Colombia de 1991, y es particularmente relevante porque en un tema muy ligado al derecho del consue en un tema muy licado al decho como es la publicidad, la misma autoridad se atreve a ligarlo a los derechos fundamentales, condenando el hecho de que se vulneran estos, en línea con los compromisos internacionales de defensa de los derechos humanos acatados por el país (SIC- Resolución 92696, 2018).

\section{Conclusiones}

1) Se puede afirmar que los derechos de consumidor, por su naturaleza, están ligados a los derechos humanos, la economía y las a los derechos humanos, la economía y las
empresas, si se tienen en cuenta los antecedes históricos, jurisprudenciales, doctrinales, y las fuentes del derecho de la actualidad, destacando asi la dignidad humana, tan ligada al derecho del consumo.

2) Se destaca así, el vínculo que existe entre el derecho del consumo y los derechos económicos, sociales, culturales y ambientales (DESCA), y es posible afirmar que, por el fin teleológico de ambos, los derechos del consumo están muy próximos a los derechos fundamentales tutelados en los diferentes aspectos DESCA.

3) Los derechos del consumo han tenido un avance jurisprudencial en Colombia y Latinoaaver mérica en los ultimos 20 años, lo cual se consdera como un paso significativo en la defens de los mismos desde una perspectiva constitucional y de los derechos humanos. Por tanto, en el futuro, el derecho del consumo puede llegar a ser mucho más significativo, como una herramienta de protección de intereses tutelados, y también como una vía de protección de interés general.

4) Es preciso decir que el avance en la discusión de los derechos del consumo y su rango de protección, desde aspectos constitucionales, jurisprudenciales y de tratados internacionales, abordado por un enfoque de los derechos humanos, puede llegar a tener un impacto positivo en las sociedades, a partir de las responsabilidades sociales corporativas, así como de una mejora en la calidad de los bienes y servicios que se tranzan en los mercados. 


\section{Referencias}

Acosta, J. (2017). 26 años de la "Constitución Económica" colombiana: entre análisis económico del derecho y análisis jurídico de la economía. Blog de Derecho de los Negocios. ttps://dernegocios uexternado.edu.co/ negociacion/26-anos-de-la-constitucion-economica-colombiana-entre-analisis-economico-del-derecho-y-analisis-juridico-de-la-economia/\#_ftnref1

Cole, J. H. (1995). Adam Smith: economista y filósofo. Laissez-faire, (2), 32-51. http://fce2. ufm.edu/jhcole/Adam\%20Smith.pdf

Constitución Política de Colombia [Const] Artículos 1, 13,78y 333.5 de junio de 1991 (Cotículos 1, 13, 78 y 333.5 de junio de 1991 (Cogov.co/inicio/Constitucion\%20politica\%20 gov.co/inicio/Constit
de $\% 20$ olombia.pd

de $\% 20$ or

Convención Interamericana contra toda forma de discriminación e intolerancia (A-69). (2013). Artículos 1-4. http://www.oas.org/ es/sla/ddi/tratados_multilaterales_interamericanos_A-69_discriminacion_intolerancia.

Corte Constitucional de Colombia. Sala Octava de Revisión, Sentencia T-291 de 2016.https:// www.corteconstitucional.gov.co/relato ria/2016/t-291-16.htm.

Corte Constitucional de Colombia. Sala Plena, Sentencia C-1141 de 2000. https:// www.corteconstitucional.gov.co/relatoria/2000/C-1141-00.htm

Corte Constitucional de Colombia. Sala Plena, Sentencia C-147 de 2017. https:// www.corteconstitucional.gov.co/relatoria/2017/C-147-17.htm

Corte Constitucional de Colombia Sala Primera de Revisión, Sentencia T-760 de 2008. https://www.corteconstitucional.gov.co/ relatoria/2008/t-760-08.htm
Corte Constitucional de Colombia. Sala Séptima de Revisión Sentencia T-161 de 2013. RELATORIA/2013/T-161-13.htm

Corte Constitucional de Colombia cera de Revisión, Sentencia T333 de 2000. https://www.corteconstitucional.gov.co/ https://www.corteconstitucional.gov.co/ relatoria/2000/t-333-00.htm

Durand Carrión, J. B. (2019). Aproximación a una teoría de los derechos humanos del consumidor en el mercado global y su tratamiento en el derecho constituciona peruano. Prolegómenos, 22(44), 117-142. http://www.scielo org co/scielo php?pi$d=S 0121182 \times 20190002001178$ script=s ci_abstract\&tlng=en

Guarnizo, D. y Narváez, A. (2019). Etiquetas sin derechos-Etiquetado de productos comestbles: un análisis desde los derechos humanos. Centro de Estudios de Derecho, Justicia y Sociedad, Dejusticia. https://dialnet.unirioja. es/descarga/libro/738751.pdf

Herrera Tapias, B. (2013). La constitucionalización de los derechos del consumidor en Colombia: un análisis desde los derechos sociales fundamentales Civilizar ciencias sociales y humanos, 13(25), cienhis s//wWW scielo. org.co/scielo, 33-48. hitp.//Www. scielo.org.co/scielo.php?pi$d=S 1657-8953201300020000$ ci_abstract\&tlng $=f$

http://www.scielo.org.co/pdf/ccso/v13n25/ v13n25a04.pdf

Ibáñez, J. (2020). La justiciabilidad directa de los derechos económicos, sociales, culturales y ambientales. Génesis de la innovadora jurisprudencia interamericana. https:// archivos.juridicas. unam. $\mathrm{mx} / \mathrm{www} / \mathrm{bjv} /$ libros/13/6407/5.pdf

ey 1480 de 2011. Por medio de la cual se expide de la cual se expide elEstatu Por mencu de la cual se otras disposiciones. D. O. No. 48220. Octubre
12 de 2011. https://www.wipo.int/edocs/lexdocs/laws/es/co/co103es.pdf

Napoleón, I. (1821). Máximas y pensamientos del prisionero de Santa Elena. La Imprenta de Villalpando.

Papacchini, A. (1998). Los derechos humanos a través de la historia. Revista colombiana a través de la historia. Revista colombiana
de psicología, (7), 138-200. https://revistas. unal.edu.co/index.php/psicologia/article/ view/16061/16942

Resolución No. 92696 de 2018. Por medio de la cual se imparte una orden administrativa. 21 de diciembre de 2018. https://www.sic. gov.co/boletin-juridico-febrero-2019/Publicidad-empleada-por-VIRGIN-MOBILE

Smith, A. (2021). La riqueza de las naciones. Smith, A. (2021). La riqueza de las naciones. Greenbooks editore. https://books.google. es/books?hl=es\&li=\&id=cV4WEAAAQBA$J \& o i=$ fnd $\& p g=P T 4 \& d q=a d a m+s m i t h+l a+r i-$ queza+de+las+naciones\&ots=YSe6oYfoh$q \&$ sig=jVRbevaNXzogsymajPkdiNRqkQo\#$\mathrm{v}=$ onepage \&q$=$ adam $\% 20$ smith $\% 20 \mathrm{la} \% 20$ riqueza $\% 20 \mathrm{de} \% 20 \mathrm{las} \% 20$ naciones\&f=false Villalba, J. C. (2018). Constitución, mercado y protección al consumidor. VI Jornadas de Derecho Constitucional Intervención del estado en la economía. Universidad Autó noma de Bucaramí. Univeridad Autónoma de Bucaramang. h 12749/12189. 

quienes han vivido de las mismas, seguirán quienes han vivido de las mismas, seguirán

\section{Lecciones de Ruanda para Colombia}

Por: Mauricio Beltrán Cristancho
Resumen

Este ejercicio surge de la reflexión sobre la experiencia que tuvo Ruanda con la Justicia Penal Internacional; allí se logra identificar las falacias a partir de las cuales se ha construido la justicia transicional en Colombia. Por más la justicia transicional en Colombia. Por más que se intenten fórmulas novedosas para comprender los hechos entre la realidad y la justicia, lo cierto es que, en la realidad existen estructuras de poder que no permiten que la justicia alcance a los máximos responsables por los crímenes internacionales. De hacerlo, esas estructuras se derrumbarían Por eso buscando fóm acción de la Corte Penal Internacional.

Palabras clave: Justicia Penal Internacional, justicia transicional, Ruanda.

Gacaca es la palabra que se refiere a un sistema de justicia tradicional que, en una lengua africana, significa el lugar donde la comunidad se ré́n pa resolver sus disputas. Gacaca se retne paction constiuye en la historia del derecho pena internacional, el sistema de justicia al que recuritó Ruanda -a inicios del presente siglopara tramitar masivamente miles de procesos en contra de los perpetradores del genocidio que fue cometido por la etnia de los Hutus en contra de los Tutsis; este hecho tuvo lugar durante cien días a mediados de 1994, donde se calculó el asesinato de por lo menos medio millón de personas, sumado además a la alarmante cifra de violación de mujeres.

Para inicios del siglo XXI el gobierno Tutsi- el cual gobierna la nación desde que tomó el poder en 1994- decide recurrir a las Gacaca: doce mi cortes se establecieron a lo largo y ancho del territorio y se desplegaron en acciones apoyadas en el hecho de que la justicia ordinaria adelantaba procesos a un ritmo que, de mantenerse, implicaría un siglo de trabajo para procesar la inmensa cifra de los crímenes cometidos. Por eso, Gacaca operaria en el tiempo en el que la justicia ordinaia adelantara los proces justicia ordinaria adelantaría los procesos en
contra de los mayores responsables.

Se trataba entonces de utilizar un sistema de justicia tradicional para tramitar miles de casos, ya que dicho sistema, como suele ocurrir, resultaba más eficiente que los sistemas ordinarios de justicia criminal, pues este se escapaba del formalismo propio de la justicia criminal. Se adujo, además, que gracias a esto se fortalecería la reconciliación y se revelaría

la verdad sobre el genocidio. "Una solución sitional justice, Rwanda. 
africana para un problema africano" fue el argumento del gobierno de Ruanda con el cual en el 2001 obtuvo el apoyo su idea.

En realidad, el espíritu altruista que inspiraba al gobierno era inexistente; estaba más preocupado con lo que desde noviembre de 1994 observaría con sospecha. En el mes de noviembre de 1994, el Consejo de Seguridad de las Naciones Unidas ordenó la creación del Tribunal especial para juzgar los crímenes. La historia constató este hecho excepcional a través de los intereses que tenían Estados Unidos, Francia, Inglaterra, que China y Rusia, los cules les incidieron tomar decisiones unánimes desde el establecimiento del Consejo de Seguridad en el año de 1948. Un año atrás se había autorizado el establecimiento del Tribunal Ad hoc para Yugoeslavia, ya que las imágenes sobre la magnitud de la carnicería en ambos lugares habían empujado a la conciencia internacional a actuar.

La finalidad del Tribunal Ad hoc para Ruanda no era sólo juzgar a los Hutus por la infernal violencia que descargaron durante cien días violencia qu en contra des incluia enjuiciar a los ciudadanos ruandeses responsables del genocidio y de otras violaciones de esa indole cometidos del 1 de enero al 31 de diciembre de 1994, en el territorio de los países vecinos" (Peter, 1997).

Como la toma del poder por parte de los Tutsis había incluido matanzas en retaliación cometidas durante el resto de 1994, el Tribunal Ad hoc estaría legalmente facultado para procesar estos hechos. Por lo tanto, las Gacaca sería estos hech desde el ano 2001 la respuesta para los triunfadores de la guera, quienes aún hoy permanecen en el poder y cuyo gobierno es uno de los críticos más conspicuos de la Corte Penal Internacional, creada en 1998 gracias -precisamente- al precedente dictado por los sendo Tributes ad hoc par Tribunales Ad hoc para Yugoeslavia y Ruanda (Erlinder, 2010). El hecho es que, la CPI basada en pruebas recogidas por el Tribunal Ad hoc Tene abiertos casos en contra de algunos "vencedores" Tutsis de la guerra.

Y es que las Gacaca tramitarían 1.2 millones de casos, pero el reconocimiento de la verdad fue un asunto puramente retórico. Así lo denunció un informe de Human Righst Watch en el 2014, en el que se afirmaba que algunos participantes de los procesos mintieron youros pricipas permanecieron en silencio: algunos por intimidaciôn; otros por corrupción; para protege a conexiones personales o simplemente po miedo a las repercusiones de sus palabras. Tampoco pudieron las Gacaca asegurar compensaciones de parte del Estado. Y de parte de los victimarios no obtuvieron restitución. Lo más que lograron de estos últimos fueron dudosas fórmulas repetidas de solicitudes de perdón después de -supuestamente- confesar (Human Rights Watch, 2014).

Pues bien, en Colombia también podríamos entender a la JEP como una solución colom biana a un problema colombiano. Como aquí en este país no hubo parte derrotada (militarmente), las negociaciones por cuatro años en la Habana se convirtieron en la justificación moral para establecer una solución legal criolla que pudiera procesar las masivas violaciones a los Derechos Humanos y al Derecho Internacional Humanitario (DHH), to como lo demandan los compromisos internacionales.
Para explicar lo sucedido de manera más precisa, el gobierno nacional junto a las FARC acordó una sali ica al obstáculo que imponía la presencia de la Corte Penal Internacional desde el año 2002; no obstante, para quienes no tienen cuidado con el origen a la justificación de la creación de un sistema institucional que vele por la justicia, aquello no será un obstáculo.

En lo establecido por la Corte Penal Internacional y nuestra adhesión a la misma, se sumaron además las dificultades que enfrentó el primer gobierno de Álvaro Uribe Vélez desde el año 2003, pues bien, para poder obte 2003, pues bien, ternacional al proceso de negociación con los paramilitares, impusieron -por primera vez- un obstáculo a la ya manía práctica colombiana desde 1958 de ocultar mediante acuerdos o pactos las estructuras criminales de poder dentro de las instituciones.

Un gobierno inmensamente popular, como lo fue el de Álvaro Uribe Vélez, había ya fracasado en el intento de brindar la desmovilización por parte de los paramilitares, a cambio de representación política e impunidad y silencio para los victimarios; así lo planteaba el fallido referendo del año 2003. La modulación hecha por la Corte Constitucional, naciente de la tercera propuesta la cual además fue convertida en la Ley 275 de 2005 y permitiría legalizar la desmovilización paramilitar.

La decisión de la Corte pareció sofocar las voces de algunos sectores liberales y de izquierda que reclamaban la intervención de qure Corte ron las negociaciones con los paramilitares, demanda por inconstitucionalidad de la norma.
Al final, la Corte adujo la fórmula establecida por la Ley de Justicia y Paz en el año 2005, que, a diferencia de las dos primeras propuestas hechas anterio gobierno, permitía reconocer los derechos de las víctimas en relación con la verdad, la justicia y reparación, sin embargo, la pena podría reducirse entre cinco y ocho años, dependiendo del grado de colaboración con la verdad que tenga la víctima.

El argumento de la Corte Constitucional para esta jurisdicción fue que, si bien era cierto que la paz era un derecho de los colombianos y un deber del Estado, la justicia para las víctimas debía tener la misma importancia.

Pero la paz no lo justifica todo. Al valor de la paz no se le puede conferir un alcance absoluto, ya que también es necesario garantizar la materialización del contenido esencial de valor de la justicia y del derecho de las víc timas a la justicia. (Corte Constitucional de Colombia, Sentencia C 370 de 2006)

Por lo tanto, el derecho que tenían las víctimas a la justicia encontraba salida al establecer como ya se mencionó, una pena máxima de como ya se mancion, una pena máxima de ocho anos para quienes confesaran sus crimenes. De este modo se inauguro el primer modelo de justicia transicional en Colombia, que -en teoría- permitiría juzgar a las violaciones masivas cometidas en contra de las normas de los Derechos Humanos y del DIH. Es decir, para evitar la impunidad se debe crea un incentivo para la confesión de los comparecientes, para quienes la confesión se torna en deber e incluso como un requisito que los bliga a reconocer su responsabilidad y contar obliga a reconocer su responsabilidad y conta los detalles a las victimas y a los familiares de
las mismas. 
La Corte aceptó además que la Ley de Justicia y Paz no tendría competencia sobre los civiles o miembros de la fuerza pública. El resultado - mien gación internacional de establecer quiénes fueron los maximos responsables, como tambien identicar las estructuras criminales de poder, las cuales propiciaron la expansión masiva de los crimenes. Esto en la practica se diluiría, mientras que, en el papel, si llegaba a suceder que durante el proceso se presentasen señalamientos a otros actores, diferentes a los paramilitares, estos hechos entonces serían investigados y juzgados por la justicia ordinaria yllí no se aplicaría el beneficio de sólo ocho ños de condena por confesar. se condena por confesar.

\section{El fracaso de la Ley de Justicia y Paz}

El Centro Internacional para la Justicia Transicional (ICTJ), institución que ya opera en Túnez, Irak, Perú, Birmania y Colombia, fue creada para

Ayudar a instituciones y a grupos de la sociedad civil-a quienes dirigen y definen el cambio en sus sociedades-a considerar medidas que favorezcan el esclarecimiento de la verdad, la rendición de cuentas y la reparación por los abusos pasados.

La fuente legal que inspira a la justicia transicional está dada por la Resolución de la Asamblea General de las Naciones Unidas del 16 de diciembre del año 2005: "Principios y directrices básicos sobre el derecho de las víctimas de violaciones manifiestas de las normas internacionales de derechos humanos y de violaciones graves de derecho internacionat humanitaio graves del derecho internacional humanitario

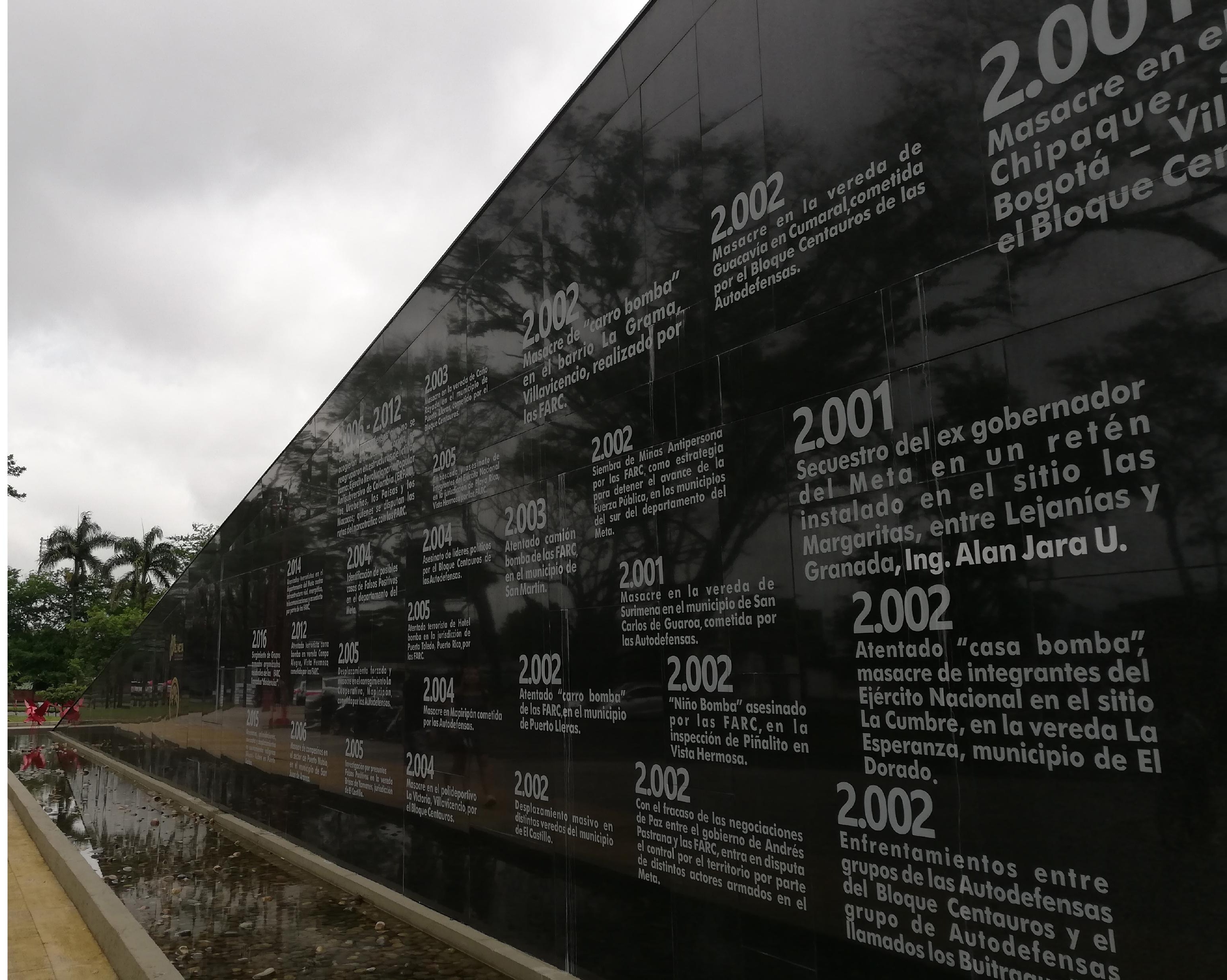


En el año 2005 se aceptó en Colombia que negociar la ley penal demostraba una gran afectación por las obligaiones intem afectación por es, especialmente por el establecimiento de la Corte Penal Internacional, que tuvo en los Tribunales Ad hoc de Yugoeslavia y Ruanda de la última década del siglo $X X$, una fuente fundamental para operar, identificar y juzgar a los máximos responsables, logrando con esto desenmascarar las estructuras de poder usadas por los mismos.

En otras palabras, el reconocimiento de la verdad tiene un objetivo mucho más impors hacer de la transición un proceso exitoso. Se trata de identificar las estructuras de poder que fomentaron, patrocinaron y ocultaron los crímenes de guerra y de lesa humanidad. Es allí, en ese espacio, donde el poder corrompido debe ser desenmascarado por la justicia transicional; sin embargo, en el caso colombiano, el mismo poder es el que ha creado y promovido los discursos grandilocuentes de supuestos procesos de paz que nos conducirían a la reconciliación.

En este sentido, la Ley de Justicia y Paz como modelo de justicia transicional fracasó, pues su gran resultado fue el de ratificar -judicialmente- que ocurrieron violaciones masivas a los Derechos Humanos, como violaciones al DIH. Lo empezó a probar la misma ICTJ estudiando sentencias de Justicia y Paz, ocho años después de haber sido instalada esa jurisdicción. Concluía en el 2014:

los tribunales aún no han proferido un fallo integra que dé cuenta de manera sistemática de la real dimensión de la estructura criminal y presente el complejo entramado de motivaciones, relaciones, alianzas y complicidades de estos grupos con políticos, empresarios, Fuerza Pública y sistema judicial. (Gaitán, 2014)

Dos años después de este informe, y ante el fracaso del referendo para ratificar los Acuerdos de Paz con las FARC, se iniciaron ejercicios académicos para tratar de valorar positivamente la efectividad que tenía esta jurisdicción para esto se estudiaron las 51 sentencias condenatorias, producidas por la misma, donde se había legalizado 6928 hechos punibles:

Con una mirada centrada en las víctimas, encontramos que la narración final de los hechos probados es un espacio de construcción de verdad judicial en el que pueden entrar en disputa los relatos de las víctimas y los de los procesados, aunque en muchos casos coinciden. (Burgos et al., 2019)

La afirmación final sobre "muchos casos" en los que "coinciden" los relatos de las víctimas y los victimarios -según los datos del mismo informe- fue falaz.

Según el estudio antes mencionado, se nos dice que en el $79 \%$ de las 51 sentencias dictadas, la base de las mismas fue el relato del victimario. Esas sentencias difícilmente se pueden clasificar como sólidas probatoriamente, ta como lo demanda el estándar en derecho penal internacional. Solo en el $15 \%$ de esas sentencias existió coincidencia entre los dos relatos, del victimario y de la víctima, lo que demuestra el pobre desempeño de esta jurisdicción. Po último, debe indicarse que en el restante $6 \%$

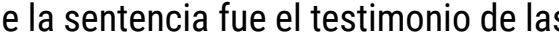
víctimas (Burgos, et al., 2019).
Nuestro argumento se ratifica y encuentra respaldo en el estudio anteriormente citado, pues bien, allí también se valor sentencias con sentencias con respecto a si ellas cumplieron con cuatro estándares: (i) determinación de móviles; (ii) determinación de circunstancias de tiempo, modo y lugar; (iii) identificación de responsables y (iv) prevalencia de testimonios como fuente probatoria de los casi siete mil hechos juzgados. Las sentencias que cumplieron con los cuatro estándares fueron calificadas como Altas; Media para los que alcanzaron a cumplir con dos o tres y Baja para los que sólo cumplieron con uno. Sólo el $1 \%$ por ciento de esos hechos (90 de 6928) lograron englobar de esos hech (90 de 6928) logr englobar los cuatros criterios que exige la categoría Alta, y en el $44 \%$ de los casos, sólo se aplicó una variable (Burgos, et al., p. 27). Dicho de otra forma, en noventa casos de los 6982 se puede aducir que existió el estándar que demanda el Derecho Penal Internacional.

Salta entonces a la vista que el reconocimiento de responsabilidad a través de una verdad detallada, anhelada para obtener el beneficio de ocho años de cárcel, concluyó finalmente de en el fracaso. Y camo ya se advirtó (estructuralmente), Justicia y Paz fue avalada por la Corte Constitucional, lo que quiere decir que se aceptó que dicha Ley no debía tener la competencia para judicializar actores distintos que no fueran desmovilizados de grupos armados al margen de la ley.

Magistrados de Justicia y Paz compulsaron copias a la justicia ordinaria: una justicia colapsada. En las 51 sentencias que se presentaron se mencionaron miembros de la presa pública e mencion y empresarios que estaban implicados en los hechos de violencia. Esto afectó a catorce generales y también al ex presidente Álvaro Uribe
Vélez. Sin embargo, no existen resultados sobre investigaciones que evidencien la voluntad desde la justicia ordinaria para determinar quie列 estructuras criminales que los amparaban.

Alli radica el gran desafío de la JEP, tras luego de tres años de abrir sus puertas. El hecho d que Justicia y Paz no haya logrado descifra las alianzas y complicidades con las que se instalaron y operaron los varios grupos criminales que se autocalificaron como $\mathrm{Au}$ todefensas, indica que, los grandes aliados, encubridores y patrocinadores públicos privados, no han sido tocados, ni señalados por los crímenes.

Enseña además que este modelo de justicia transicional depende de las confesiones de los perpetradores responsables de crímenes de guerra y delitos de lesa humanidad, donde luego estas confesiones deben ser contrastadas y valoradas si son lo que se esperaba, 0 si son suficientes para el esclarecimiento de la verdad; para finalmente concluir que debería concedérsele al responsable, el beneficio de una pena de ocho años por cometer la peor clase de crímer cionó, y la historia puede repetirse.

Tres años después de haber abierto sus puertas, ya existía en la JEP un pesimismo creciente sobre sus resultados. La JEP estaba soportada en hechos concretos; el primero de ellos versaba en que los victimarios negaban su responsabilidad de los hechos, e incluso ponían en duda lo sucedido. Dentro de algunos ejemplos que evidencian tal situación, nos encontramos con un ex dirigente de las FARC quien refutó el caso

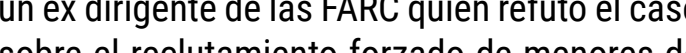
sobre el reclutamiento forzado de menores de se le sumaron las palabras del general Mario 
Montoya, quien desmintió y negó la existencia de los falsos positivos.

Estos actos violentan el acuerdo mismo y lo establecido expresamente en el Acto Legislativo 01 de 2017 y la Ley Estatutaria de la JEP. Producto de cuatro años de negociación en la Habana, los comparecientes, a quienes por adelantado se les ha concedido el beneficio de permanecer en libertad, no han cumplido con lo que se comprometieron para que sus casos fueran tramitados por este segundo ejercicio de justicia transicional, para que así reconocieran la existencia del hecho mismo frente a us responsabilidades condiciones de comandantes.

Las actitudes renuentes frente a la verdad por parte de los actores no han sido calificadas por la JEP en un plazo razonable de acuerdo con el acuerdo final ratificado por la Corte Constitucional, donde tales actos son asumidos como una violación al régimen de las penas propias, e implicaría que se hubiera procedido a iniciar la etapa adversarial, previa proctura de incidente para pérdida de benefi-

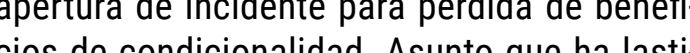
cios de condicion lastimado aún más la legilimidad de la institución e inicia el ahogamiento de la segunda justicia transicional intentada para eludir la acción de la Corte Penal Internacional.

La razón es simple: reconocer la verdad implica desnudar estructuras criminales de poder $y$, en términos personales, estar a merced de la humillación frente a la nación, inaceptable para cualquier victimario, especialmente para os articuladore los a culicular cambio, el camino de hacer reconos parciales, siempre y cuando sea necesario, permite no amenazar su posición dentro de esas estructuras y de este modo seguir alabando al tirano.

Por lo tanto, como en el caso de Ruanda que entendió el potencial que tiene la Justicia Pena Internacional para desarticular las estructuras de poder, y que juzga a grandes responsables, la acción de la Corte Penal Internacional sólo seguirá aplazada. La misma, cada vez tendrá más información para un día poder solicita a Colombia la detención y la entrega de personajes de lado y lado. Por eso, la disputa por el control del Estado continuará, pues si llega ese día, es muy posible que los primeros entregados formalmente seŕn los enemigos. Yasí se comprobá que el discurso sobre la Yaz y la reconciliacín no era más qube la paz y la reconciliación no era más que una forma de eludir -por ahora- la única maner de justicia que el mundo ha encontrado para tener a "raya" a la atractiva invitación de la maldad que suele enamorar a quienes viven por y para el poder.
Referencias

Burgos, M., Chaparro, L., Clavijo, V., Gómez, A. Medina, C., Muñoz, P., Rico, D. y Velasco, J. (2019). La verdad en las sentencias de justicia y paz. CITpax.

Corte Constitucional de Colombia. Sentencia C 370.18 de mayo de 2006. https:// www.corteconstitucional.gov.co/relatoria/2006/C-370-06.htm

Erlinder, P. (2010). The UN Security Council Ad Hoc Rwanda Tribunal: International Justice or Juridically-Constructed "Victor's Impunity"? DePaul Journal for Social Justice 4(1) 131-214. https://via library depauledu/cgi/

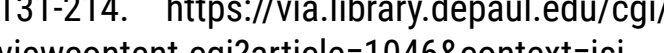
viewcontent.cgit.article=1046\&context=jsj Gaitan, 0. (2014). La construccion de sentencias de Justicia y Paz de la "parapolítica". Centro . Human Rights Watch. (2014). Ruanda: justicia después del genocidio: 20 años después. https://www.hrw.org/news/2014/03/28/ rwanda-justice-after-genocide-20-years

Peter, M. (1997). El Tribunal Penal Internacional para Ruanda: sancionar a los asesinos. RevisTa Internacional de la Cruz Roja https://www icro org/es/doc/resources/documst/misc/5tdl75 htm 
Con tan solo 64 años de fundada la capital de la Nueva Granada, Santa fe de Bogotá se vio envuelta en el primer caso registrado de corrupción de esta colonia española. El escándalo se originó por la pérdida de cinco mil pesos oro enviados por el gobierno español a las arcas del Virreinato, el protagonista del escándalo, don Francisco Sande, fungía como presidente de la Real Audiencia; la historia cuenta que el dinero le fue dado en efectivo en la ciudad de Madrid, pero que, nunca fue entregado para los fines reales.

La desaparición del dinero generó protestas por parte de los nativos, dados los atropellos y malos comportamientos cometidos por Sande. En vista de esto, el gobierno español designó a Andrés Salierna de Mariaca para que investigara los hechos. No obstante, el presidente Sande dejó correr el rumor que aquel dinero había sido utilizado para sobornar a Mariaca, con el fin de salir absuelto de las investigaciones. A través de este hecho, podemos ver cómo nace la desinformación, la corrupción y los sobornos, los cuales han avivado el derecho a la protesta, incluso desde hace siglos.

El desenlace del primer caso de corrupción, documentado en los archivos de la época, cuenta que el visitador Mariaca, al enterarse del rumor que lo involucraba, decidió citar al arzobispo y a los miembros de la Real Audiencia -quienes eran el máximo tribunal judicial- para expresarles en su lecho de enfermedad:

Juro por mi alma que soy inocente. Nunca he visto esos cinco mil pesos. Ni uno
En esta hora de mi muerte lo desafío para que comparezca conmigo ante Dios y responda por su infamia y su crimen -ya moribundo prosiguio- Sande ha ofendido a la divina providencia haciéndose pasar por un hombre piadoso y honrado. Pero les garantizo que antes de que pasen nueve días, él y yo no veremos en el tribunal de Dios. Allí no caben falsedades ni engaños. (Gossaín, 2017)

El investigador murió el 9 de septiembre de 1602, su comitiva corrió la misma suerte po esos días, la causa de las muertes se dio posiblemente por envenenamiento luego de haber asistido a una cena al llegar al pueto de Honda. Estos acontecimientos son narrados llibro El cam (1859) por el periodistos en elitor Elcamero (1859) por el periodista y escritor Juan Rodríguez Freyle, quien fue testigo de los hechos.

En el año de 1602 vino como visitador de esta Real Audiencia el licenciado Salierna de Mariaca, que era oidor en México, y el cual de una comida que comió en el puerto de Honda, murió en Santa Fe, y murieron todos los que comieron con él. $Y$ a los nueve días

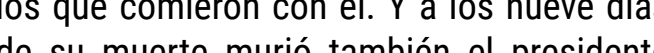
don Francisco de Sande, que habia sido emplazado por el visitador Mariaca para que se presentaran juntos en un juicio de Dios. ( $p$ 366)

La muerte del presidente Sande el 18 de septiembre de 1602 fue declarada como muerte natural por su médico de cabecera el doctor Auñón. El público incrédulo comentaba que si este hecho se debía a la simple casualidad o si por el contrario se debía a los azares del

Estudiante del programa de Comunicación Social y Periodismo, Corporación Universitaria del Meta -UNIMETA. Correo: mario.castillo2050@gmail.com 


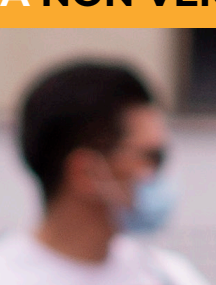

IIIn

NO NOS

$5 !$ FALTA DINERO, NOS SOBRAN
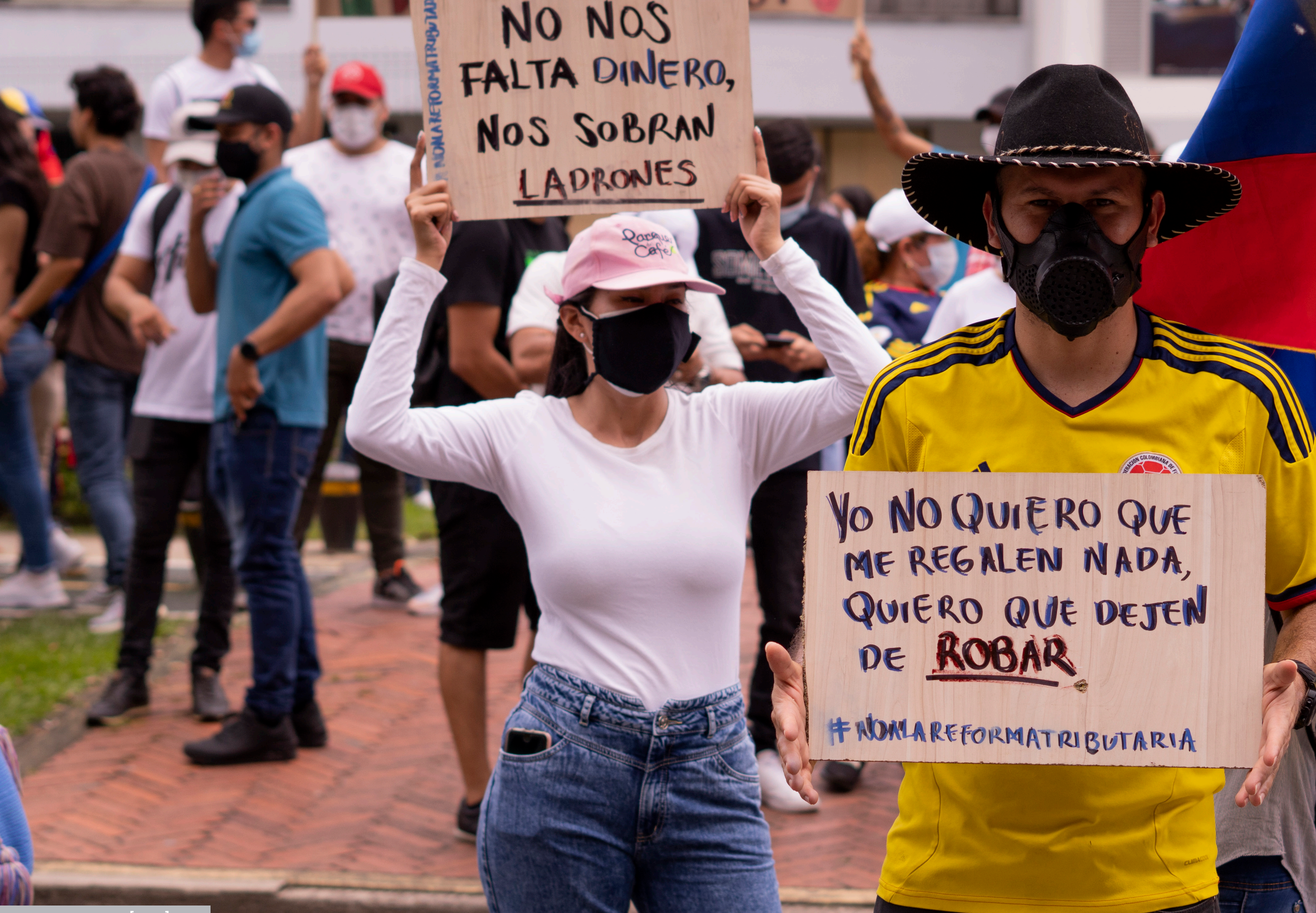
LADRONES

$+$
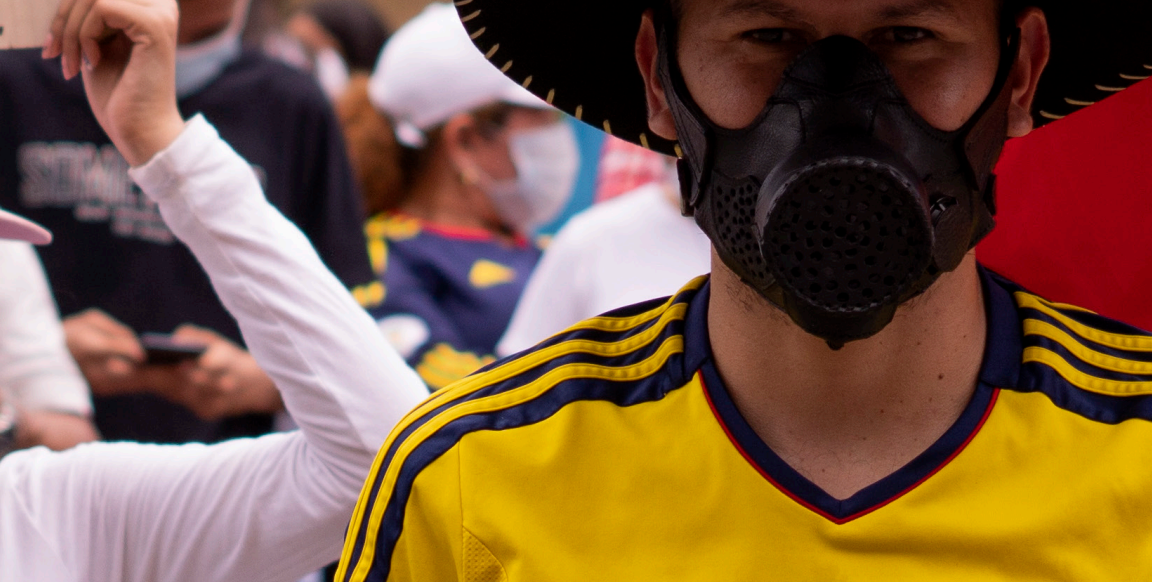

d) 11

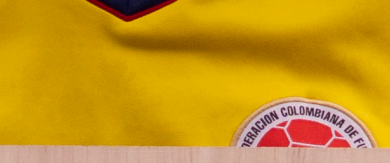

Yo NOQUIERO QUE ME REGALEN NADA, QUIERO QUE DEJEN DE ROBAR 
destino, porque justo la predicción que hizo el investigador en su lecho de muerte, terminó por cum dias siguien tanto del presidente como del investigador el caso nunca pudo resolverse y el dinero nunca apareció

La práctica del apoderamiento de los recursos públicos se quedó entre nosotros. Cuántas obras y cuántos proyectos han quedado inconclusos; cuánta rapiña al erario del país hemos tenido que soportar por siglos por culpa de mecanismos corruptos. Situaciones como estas, sin lugar a dudas, han contribuido al aumbe ( de la brecha social, lo cual ha generado además inseguridad, mala educación, pésima atención en los servicios de salud y hasta precariedad en los servicios básicos. Estos factores juntos han llevado a cientos de colombianos a caer en la pobreza total y, por tanto, a adoptar una indigna calidad de vida. Aunque la corrupción sea un mal que se observa a nivel mundial, Latinoamérica demuestra una marcada diferencia, pues la impunidad y el lento sistema judicial favorecen a los saqueadores de turno que se suman a la pr suman a la protacion de los paras as fiscales y bancarios donde los ladrones de cuello blanco son expertos en ocultar sus botines. Acá la malversación de fondos es frecuente y no se percibe si los montos son menores, sólo somos conscientes de ello cuando los medios de comunicación hacen referencia a hurtos de grandes proporciones.

En Colombia los grandes escándalos relacionados con el saqueo al erario público son abundantes, así lo indican las cifras. Reco dantes, asi lo indican las cifas. Recordemos tos en los últimos años:
En 1984 se produjo el gran robo electrónico al estado colombiano, fueron 13.5 millones de dólares que el estado colombiano poseía en Manhatan de Londres y que Roberto Soto Prieto transfirió a sus cuentas personales. Fue condenado como reo ausente a siete años de prisión, pidió asilo político en Austria, pero nunca pagó un solo día de cárcel por su delito.

En la primera etapa de Foncolpuertos (Colpuertos 1991) se pagó quince mil millones de pesos en demandas y reajustes de quidación, todas ellas fraudulentas. En su segunda etapa entre 1992 y 1993 la empresa liquidó alededor de 6.609 funcionarios por in un costo de 55.300 millones de pesos, sin embargo, meses despues cursaban contra la entidad más de 6.000 demandas por un valo de 22.600 millones de pesos. Todo esto fue posible por la complicidad que tuvieron los funcionarios de Colpuertos, el Fondo Pasivo Social (Foncolpuertos) un grupo de abogados, quienes cometieron este gran robo.

En 1993 la Hidroeléctrica del Guavio hurtó alrededor de quince mil millones de pesos el único condena fue Fabio Puyo Vasco, quien huyo chulen huy del país. Pese a que fue capturado en Estados Unidos y en Españ ción y por tanto no pagó un solo día de cárcel.

Tenemos también el famoso caso de la EPS Saludcoop, donde se hurtaron aproximadamente 1.4 billones de pesos, dinero que estaba destinado para programas de salud de los colombianos. El dinero desapareció y el acusado Carlos Palacino fue capturado en marzo de 2018 por Presunto celito de peculado por apropiación el presunto delito de peculado por apropiación a favor de terceros. Su castigo fue no pode pagó una demanda de 56 millones de pesos.
El carrusel de la contratación se llevó 2.2 billones de pesos los implicados fueron Samuel Moreno y su he Moreno y su hermano Iván Moreno, quienes crearon un entramado de corrupción para adjudicar irregularmente contratos de grandes obras de infraestructura para el distrito capital como también a nivel nacional. En este caso hay condenados a prisión (el clan de los Nule), y de la devolución de los recursos poco se ha logrado.

Otro caso de corrupción pasó en el marco de los Juegos Nacionales en su vigésima versión en el año 2015 y también en la cuarta versión de los Juegos Parana de los Juegos Paranales. Gran parte de los recursos que debían ser usados para la construcción de escenarios deportivos terminaron en los bolsillos de personas corruptas: 66.000 millones de pesos fue el dinero hurtado en estos juegos, según lo indican los informes de la Contraloría General de la República.

Por último, tenemos a Reficar, donde se calcula que la pérdida fue de cinco billones de pesos en supuestos sobrecostos para la construcción de una refinería en Cartagena. Este caso convertido convertido en uno de los mayores detrimentos patrimoniales en los últimos años. Las investigaciones empezaron en 2016 y cinco años después del fallo de la Contraloría General de la República, se dictaminó responsabilidad fiscal de dos presidentes y tres vicepresidentes de la empresa, siete miembros de su junta directiva y cuatro empresas contratistas. El robo de Reficar asciende a la suma de 2,9 billones de pesos.

Las grandes obras de infraestructura que se logran construir en el país, terminan siempre con demandas, inmensos sobrecostos e incumplimientos de entrega. Nuestro país sería diferente si las inversiones de todos estos recursos llegasen al destino de sus iniciales propósitos; cambiaría la calidad de vida de la gran mayoría de colombianos y quizá no esta-

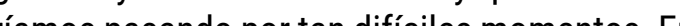

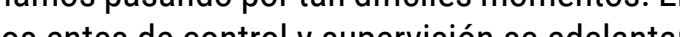
a tiples casos de corrupción que hay dentro de nuestro sistema, tales son los casos como el del cartel de la toga; el cartel de la hemofilia; el cartel del sida, y las múltiples demandas que a diario se radican, por los múltiples proyectos que sufren desfalcos a causa de la corrupción. Tristemente parece que en nuestro país la palabra desarrollo es sinónimo de corrupción.

\section{Referencias}

Gossaín, J. (2017). El increíble primer escándalo de corrupción en la historia de Colom bia. El Tiempo. https://www.eltiempo.com/ colombia/otras-ciudades/el-primer-escan dalo-de-corrupcion-en-la-historia-de-colombia-139934

Rodríguez Freyle, J. (1859). El carnero. Ed. Pizano i Pérez. 
El temor es una emoción inherente al ser humano. Está en nosotros desde que nacemos hasta el último dia de nuestra existencia. Es muy importante saber convivir con él y aceptar que siempre nos acompañará en cualquier decisión que tomemos; a veces tratará de acobardarnos para que no intentemos lo que deseamos y así evitar el fracaso o la our deseamos y asi evitar el fracaso o la burla; o tambien nos puede hacer creer que no estamos capacitados para lograr materializar nuestros sueños. Sumidos en este tipo de actitudes, van pasando los años y dejamos que se aplacen todos esos anhelos. Ricardo Arévalo enfrentó una realidad logró vencer sus temores y empezó a construir un nuevo camino: de su familia y en especial el de Sonia Yuran (una de sus hijas), Ricardo pudo convocar un grupo de personas, entre ellos familia, amigos, conocidos y también ajenos a sus círculos. Entre este grupo habia personas con conocimientos en el area audiovisual desde la parte empírica; profesionales de diferentes áreas del conocimiento; incluso había personas que estaban allí simplemente como interesados en aprender la profesión del comunicador social y peirodisticipes de su proyecto y lo acompañamos en su búsqueda por materializar este sueño llamado profesionalización

La propuesta se elevó ante el rectorado de UNIMETA el 11 de abril del 2019; teníamos presente las posibilidades de aceptación y viabilidad que ya se estaban cumpliendo por parte del personal de Asopemec en el Meta. Estas personas encontraron desde el empirismo la posibilidad de que sus conocimientos fueran reconocidos y validados por medio de exámenes de suficiencia.

Teniendo este antecedente se solicitó la profesionalización de personas que han tenido alguna trayectoria en los medios de comunicación, para que el ejercicio académico pe mitiera cualificar los aportes de ellos en sus areas de trabajo, y que además cumplieran con un minimo de certificaciones y cursos que demostraran sus experticias. Para esto, se inició la convocatoria por medio del voz a voz y de las redes sociales, buscando personas que estuvieran interesadas en continuar sus años de estudio y cendicar su experiencia en los mexperiencia en lo me convocatoria surgleron gran cantidad de aspirantes, cuyas experiencias estaban relacionadas con los diferentes medios de comunicación del país.

Cerca de cien personas conformaron el grupo por medio de WhatsApp, allí estaban presentes los interesados; se conocieron diferentes perfiles, sus expectativas y las posibilidades de iniciar periodos académicos en la facultad de Comunicación Social y Periodismo.

Internamente se conocía la evaluación de la propuesta por parte de la UNIMETA. Para este proceso tardaron alrededor de un año en revisar los procesos de estudio del pénsum y en la contemplación de qué tan viable era el proyecto para transformarlo en la cobertura como programa académico de la Institución.

Gracias a las posibilidades, logró aprobarse la propuesta apoyada por la decanatura y la vicerrectoría, quienes dieron la posibilidad a 

48 de la Constitución Política de Colombia de protección especial a personas con debilidad

Por: Suhjaila Zuaín Sayur
La seguridad social en Colombia es un derecho irrenunciable e inherente de la persona y, por lo tanto, es de difícil tratamiento, puesto que toca aspectos de la economía y la ciencia política; aspectos de la econ es una institución legal, reglamentada especialmente para proter los llamados derechos fundamentales, entre los que se encuentran la vida, la salud y la integridad de todos los ciudadanos, asunto consignado en el artículo 1991 (título 2 de los derechos, las garantías y los deberes, capítulo 2 de los derechos sociales, económicos y culturales). El Estado es el responsable de proteger y no vulnerar ese derecho fundamental asumiendo su rol como derecho funda de prol asumiendo su rol como característica sustantiva d del estado moderno.

Así, a partir de la entrada en vigor de la Constitución Política de 1991, el Estado colombiano debió adecuar su gestión para garantizar los principios del Estado Social de Derecho: dignidad humana, solidaridad e igualdad en la manifiesta. Al respecto, el tratadista Julio Armando Grisolia (2003) dice que:

El derecho de la Seguridad Social es el conjunto de normas jurídicas que regulan la protección de las denominadas contingenprotección de las denominadas contingencias sociales17, como la salud, la vejez o la desocupación. Se trata de casos de necesidad biológica y económica. Es una rama del derecho que ampara al trabajador dependiente, al autónomo y también al desempleado, de las contingencias de la vida que pueden disminuir la capacidad de ganancia del indi-

de medidas y garantías adoptadas a favor de los hombres para protegerlos contra ciertos riesgos. (p. 923)

En la Colombia de hoy, este derecho se encuentra fracturado de tal manera que es una incertidumbre y causa angustia el pensionarse, pues no solo basta con cumplir los requisito de ley para la misma (que ya son confusos), sino que también hay que considerar el arbitrio de ciertos personajes políticos que juegan sus cartas pagando favores politicos.

La segunda edición del libro "Fundamentos de la seguridad social colombiana", autoría del profesor José Eduardo Bernal Barrera, abogado de profesión y experto laboralista en seguridad social, contribuye en esas 170 páginas ilustradas para que la comunidad educativa de manera cómoda y didáctica comprenda todo lo referente a la seguridad social: desde su recuento histórico en el mundo, luego con nuestra Carta Magna como norma de normas, pasa por las mil y una reformas de la ley 100 de 1993 y sus decretos reglamentarios, hasta aterrizarnos en esta problemática social que vive día a dí el colombino promedio que va vive va

\section{Referencias}

Constitución Política de Colombia [Const]. Art. 48.7 de julio de 1991 (Colombia).

Bernal, E. (2021). Fundamentos de la seguridad social colombiana. Editorial UNIMETA. Grisolia, J. (2003). Derechos del trabajo y de la seguridad social. Ediciones Desalma Lexis Nexos.

Abogada. Jefe del Centro de Investigaciones Socio Jurídicas "Jorge Eliécer Gaitán", Corporación Universitaria del Meta -UNIMETA. Correo: suhjaila.zuain@unimeta.edu.co 


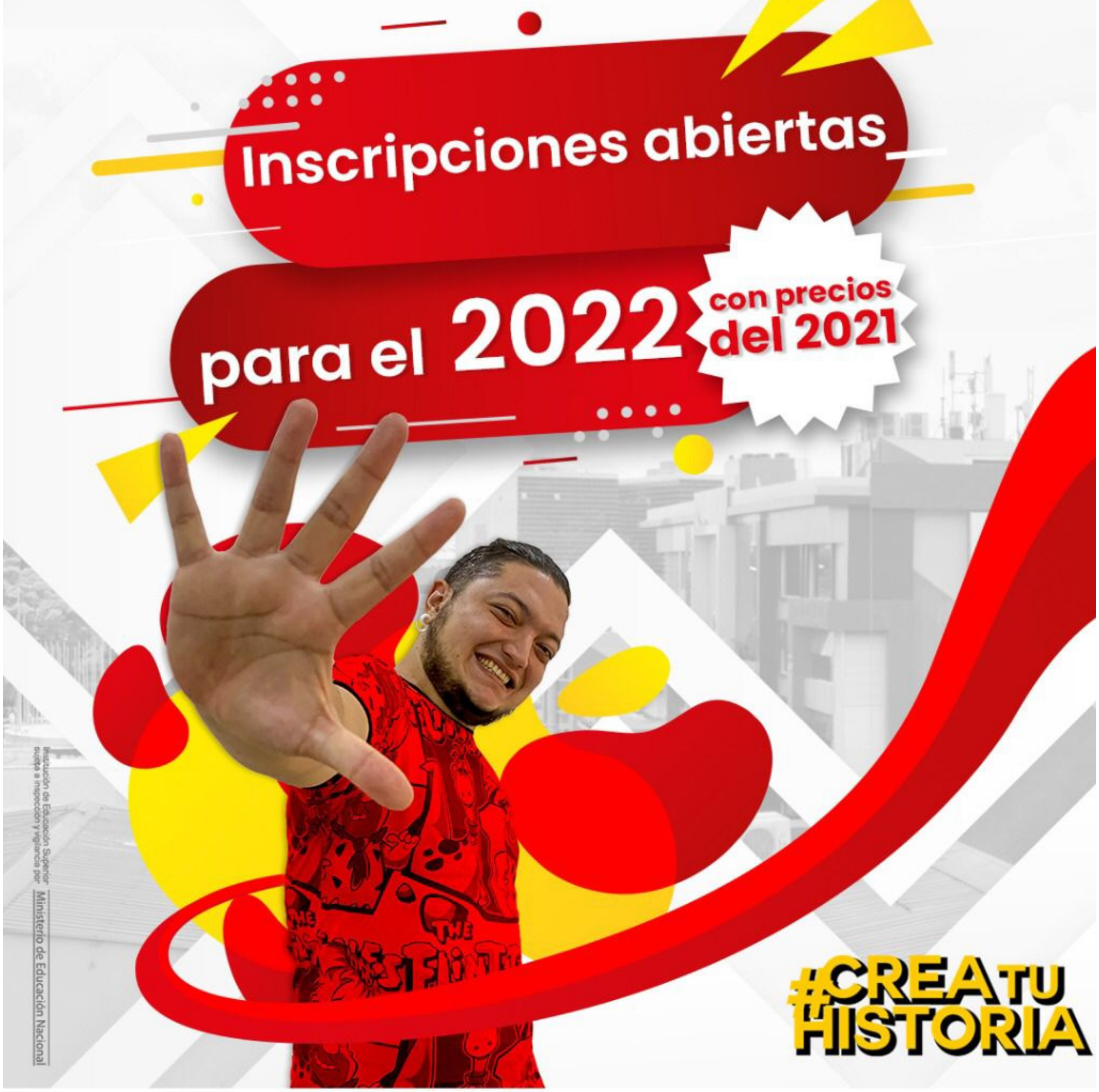

Más información

3228488208 - 3228488209 - 3228488204

promocioninstitucional@unimeta.edu.co

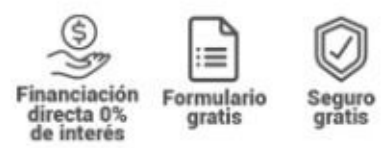

Válido hasta el 30 de diciembre de 2021. 